\title{
Association between Smoking and Noise-Induced Hearing Loss: A Meta-Analysis of Observational Studies
}

\author{
Xiaowen $\mathrm{Li}^{1}{ }^{1}$, Xing Rong ${ }^{2}$, Zhi Wang ${ }^{2, *}$ and Aihua Lin ${ }^{1,3, *}$ \\ 1 Department of Medical Statistics, School of Public Health, Sun Yat-sen University, Guangzhou 510080, China; \\ lixw23@mail2.sysu.edu.cn \\ 2 The Institute of Occupational and Environmental Health, Guangzhou Medical University, 1 Tianqiang St., \\ Huangpu West Ave., Guangzhou 510620, China; 18680503245@126.com \\ 3 Department of Health Service and Management, Xinhua College of Sun Yat-sen University, \\ Guangzhou 510520, China \\ * Correspondence: zhi_wang@outlook.com (Z.W.); linaihua@mail.sysu.edu.cn (A.L.)
}

Received: 7 January 2020; Accepted: 10 February 2020; Published: 13 February 2020

\begin{abstract}
The purpose of this study was to synthesize the results of previously published observational studies through meta-analysis to clarify the association between smoking and noise-induced hearing loss (NIHL). We searched several databases as of October 2019. Based on the results of heterogeneity analysis ( $Q$ statistic and $I^{2}$ statistic), a fixed effect model (for no heterogeneity; $Q$ test $P>0.1$ and $I^{2} \leq$ $50 \%$ ) or a random effects model (for heterogeneity) was used to calculate the pooled odds ratios (ORs). We explored the potential dose-response relationship between smoking and NIHL as well. In total, 27 studies involving 30,465 participants were included. Compared with non-smokers, the pooled OR of current smokers was 2.05 (95\% Confidence interval (CI): 1.71-2.46), and of former smokers was 1.11 (95\% CI: 1.05-1.18). We found a curve linear association between an increasing number of pack-years (packages/day $\times$ smoking years) and risk of NIHL. The dose-response meta-analysis suggested that when the number of pack-years was less than fifteen, the risk of NIHL was increasing, and the highest combined OR was 5.25 (95\% CI: 2.30-11.96) for pack-years of fifteen. After fifteen pack-years, the pooled OR had a slow decline. Our study indicated that smoking is a risk factor for NIHL. Current smokers have a higher risk than former smokers, and there is a positive dose-response relationship between smoking and NIHL.
\end{abstract}

Keywords: noise-induced hearing loss; smoking; meta-analysis; dose-response relationship

\section{Introduction}

Noise-induced hearing loss (NIHL) is chronic and irreversible sensorineural hearing loss resulting from long-term exposure to noise. It affects the daily social life of patients and brings a huge burden on society and economy. According to the $\mathrm{WHO}$, around 466 million people worldwide suffer from disabling hearing loss, and it is estimated that unaddressed hearing loss poses an annual global cost of US $\$ 750$ billion [1]. About $16 \%$ of the world's disabling hearing loss is caused by noise exposure in the workplace [2], and NIHL has become one of the most important work-related diseases around the world. In addition, it is estimated that nearly 600 million workers worldwide have a history of occupational noise exposure [3].

NIHL is related to multiple factors. In addition to occupational noise, other factors (such as organic solvent [4], high-temperature [5], no use of hearing protection device [6], alcohol [7], genes [8], comorbidity [9], etc.) may be independent factors or have a synergistic effect with noise to increase the risk of NIHL. Smoking is a risk factor for many illnesses, and many published studies [10-13] 
have suggested that it may also be associated with NIHL. Some toxic and harmful substances like nicotine from tobacco burning may affect hearing. However, smokers are widely distributed all over the world, especially in China, with an estimated more than 300 million people (one third of the total number of smokers worldwide) [14]. As a lifestyle that is one of the leading preventable causes of death but difficult to quit, the association between smoking and NIHL has drawn increasing attention. Although a meta-analysis [15] has concluded that smoking is associated with hearing loss, prior analyses focused on people without occupational noise exposure, and the pathogenesis of NIHL is different from other hearing loss. Therefore, we conducted a meta-analysis of observational studies to assess the relationship between smoking and NIHL in noise exposed workers.

\section{Materials and Methods}

\subsection{Literature Search Strategy}

The meta-analysis was performed in accordance with the PRISMA guidelines [16]. We conducted a literature search in Pubmed, Embase, Web of Science, Scopus, Wanfang, and CNKI databases for studies published in English and Chinese up to October 2019. The search terms were NIHL and smoking with their synonyms (noise induced hearing loss or noise induced deafness or noise deafness) AND (smoke or smoker or smoking or cigarette or tobacco or cigar). We also reviewed the reference lists of retrieved articles for other pertinent papers.

\subsection{Inclusion and Exclusion Criteria}

The inclusion criteria were as follows: (1) the study design was a cohort, case-control or cross-sectional; (2) study population had a history of occupational noise exposure; (3) NIHL was clearly defined as the outcome; (4) study provided odds ratio (OR) or relative risk (RR) with the corresponding $95 \%$ confidence interval (CIs). If a study was published in multiple papers, we included only one with sufficient information. Review, conference, or experimental articles were excluded.

\subsection{Data Extraction and Quality Assessment}

Two investigators (X.L. and X.R.) independently extracted the following information from eligible studies: first author, year of publication, country, source of participants, study design, sample size, age, gender, diagnostic of NIHL, smoking information, adjusted OR/RR with $95 \%$ CIs, and adjusted or matched variables. Disagreements were solved through discussion.

We used the Newcastle-Ottawa Scale [17] to assess the quality of cohort or case-control studies. The judgement was based on three areas: selection of participants, comparability of groups, and exposure/outcome ascertainment. Scores ranging from 0 to 9 reflect an improvement quality of studies. For cross-sectional studies, an 11 items checklist recommended by Agency for Healthcare Research and Quality (AHRQ) [18] was applied. Articles scoring 0-3 points, $4-7$ points, and 8-11 points were classified as low, moderate, and high-quality studies.

\subsection{Statistical Analysis}

OR was used as a measure of the association between smoking and NIHL. Due to the low incidence of NIHL, the reported RR was approximately considered as OR. When smoking status was just divided into smokers and non-smokers, smokers were defined as current smokers. In addition, when OR was reported separately at different smoking levels, we extracted the highest level of results. Two articles $[19,20]$ separately estimated OR and 95\% CI in two levels of noise exposure, and they were treated as different studies in the analysis. 
Before calculating the overall pooled OR, we used $Q$ test and $I^{2}$ statistic to quantify the heterogeneity of studies. If $P$ value for $Q$ test was more than 0.10 and $I^{2}$ value was less than $50 \%$, we used a fixed effect model. Otherwise, a random effects model was applied [21]. And we did subgroup analyses according to study design (cohort vs. case-control vs. cross-sectional), gender (both vs. male vs. female), mean age ( $<40$ vs. $\geq 40$ ), race (Mongoloid vs. Caucasian vs. others), quality of studies (high quality vs. moderate quality), number of adjusting variables ( 0 vs. $\geq 1)$ and publication year (<2010 vs. $\geq 2010$ ). The race was roughly classified on the basis of the country reported in the study. People living in China, Japan, Malaysia, Indonesia, Brunei, and Nepal were seen as Mongoloid; Caucasians were from the United States (USA), Britain, Italy, Iran, Denmark, Switzerland, and Germany; Brazilian was classified separately.

In addition, a dose-response analysis of pack-years and NIHL was estimated. Pack-years is a measure of the amount of cigarettes a person has smoked over an extended period, which is equal to the number of packages (/20 cigarettes) per day multiplied by the smoking time (/years). For example, smoking one package every day for two years equals to two pack-years. Articles that provided at least three quantitative categories were included in this calculation. Since all studies reported dose in groups, we assigned the midpoint of the group range as the dose value, and for the highest open-ended group, multiplied the lower limit by 1.5 times. We evaluated the potential curve liner relationship between the number of pack-years and NIHL by using restricted cubic splines with three knots $(10 \%$, $50 \%$, and $90 \%$ ) of the distribution [22,23]. We tested whether the coefficient of the second spline is equal to zero to determine whether the relationship is linear or non-linear. A coefficient not equal to zero for the second spline indicates a non-linear relationship [24].

A sensitivity analysis was also conducted to see the influence on the overall result by omitting each study. In addition, we recalculated the pooled OR after omitting those articles with extremely high ORs $(>10)$. We used Begg's rank correlation test and Egger's linear regression test to assess potential publication bias [25,26]. If publication bias was indicated, further trim-and-fill method [27] was used to recalculate the pooled OR. All statistical analyses were performed using $\mathrm{R}$ version 3.6.0 (R Foundation for Statistical Computing, Vienna, Austria). For all statistical tests other than $Q$ tests, which have different statistical significance criteria as described above, a two-sided $P$-value $<0.05$ was considered statistically significant.

\section{Results}

\subsection{Literature Search}

Based on the database and search terms, we obtained 1541 articles to screen. Through browsing titles and abstracts of papers, we excluded 1467 records. After retrieving and reviewing 74 full articles, we excluded 47 records. Seven studies were excluded because participants in the research didn't have a history of occupational noise exposure. A further 30 studies were excluded because they didn't provide effect size estimate and 95\% CIs to calculate the pooled OR. 4 studies were excluded because they used auditory threshold as outcome. Two studies were excluded because results were repeatedly reported in other articles. Four studies not published in Chinese or English were also excluded. Our meta-analysis includes 27 studies $[7,10-13,19,20,28-47]$ in this meta-analysis. Selection details are shown in Figure 1. There were four cohort studies, two case-control studies, and 21 cross-sectional studies. 
Studies identified through database searching $(\mathrm{n}=$

1541):

Pubmed $(n=152)$, Embase $(n=95)$, Web of Science ( $n$

$=302)$, Scopus $(\mathrm{n}=924)$, Wanfang $(\mathrm{n}=45)$, and

$\operatorname{CNKI}(\mathrm{n}=23)$

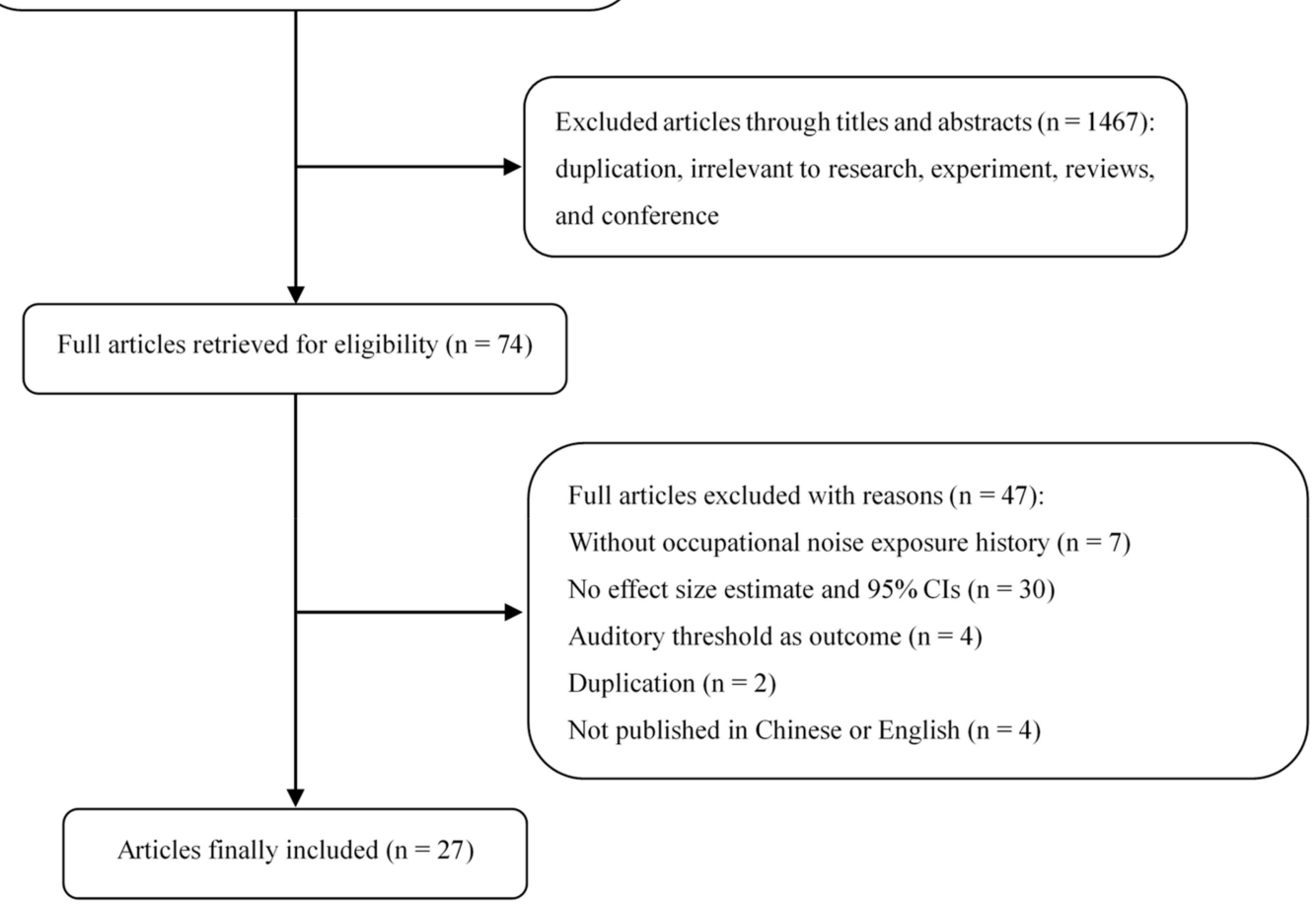

Figure 1. Literature search and selection flowchart.

\subsection{Characteristics of the Included Studies}

Table 1 shows the main characteristics of 27 studies included in our meta-analysis. Studies were published between 1987 and 2018. And a total of 30,465 workers were included in our review. Among all included studies, 18 studies were from Asia; 5 studies were from Europe; 3 studies were from North America, and 1 study was from South America. The diagnostic criteria showed differences among these studies; 16 studies were based on speech frequency, and 11 studies were based on high frequency. In addition, the quality assessment scores for the 4 cohort studies were in the range of 6-8, and the average score was 7.25 points. For two case-control studies, the scores were 7 and 8 points. There were 21 cross-sectional studies with the scores ranging from 6 to 10, and the average score was 8.14 points. 
Table 1. Main characteristics of 28 included studies on smoking and NIHL risk.

\begin{tabular}{|c|c|c|c|c|c|c|c|c|}
\hline $\begin{array}{l}\text { First Author } \\
\text { and Year }\end{array}$ & Country & $n$ & $\begin{array}{c}\text { Mean Age/Age } \\
\text { Range }\end{array}$ & Gender & $\begin{array}{c}\text { Smoking } \\
\text { Information }\end{array}$ & Diagnostic Criteria of NIHL & $\begin{array}{c}\text { Adjusting or Matching } \\
\text { Variables }\end{array}$ & $\begin{array}{c}\text { Quality } \\
\text { Assessment }\end{array}$ \\
\hline \multicolumn{9}{|c|}{ Cohort study } \\
\hline $\begin{array}{c}\text { Dement, } 2018 \\
{[11]}\end{array}$ & USA & 4275 & 59.2 & Both & $\begin{array}{l}\text { Never smoked, } \\
\text { Past smoker, } \\
\text { Current smoker, } \\
\text { Smoking } \\
\end{array}$ & $\begin{array}{l}\text { Index weighted average threshold } \\
>25 \mathrm{~dB} \text { at } 1,2,3 \text {, and } 4 \mathrm{kHz}\end{array}$ & $\begin{array}{l}\text { Age, race, sex, organic solvent } \\
\text { exposure, duration of trade } \\
\text { work, loud or very loud noise } \\
\text { exposure, hypertension } \\
\end{array}$ & 8 \\
\hline $\begin{array}{c}\text { Pettersson, } 2014 \\
\text { [30] }\end{array}$ & Sweden & 184 & NA & Male & $\begin{array}{c}\text { Smoker, } \\
\text { Non-smoker }\end{array}$ & $\begin{array}{c}>30 \mathrm{~dB} \text { at } 0.5 \mathrm{kHz} \text { or }>25 \mathrm{~dB} \text { at } 1-2 \\
\mathrm{kHz} \text { and }>25 \mathrm{~dB} \text { for at least one of } \\
\text { the frequencies of } 3,4,6 \mathrm{kHz}\end{array}$ & $\begin{array}{l}\text { VWF in the right hand, age, } \\
\text { exposure }\end{array}$ & 8 \\
\hline $\mathrm{Li}, 2008[47]$ & China & 408 & 26.5 & Both & $\begin{array}{c}\text { Smoking number } \\
\text { per day: 0, -10, } \\
10-20,>20\end{array}$ & Hearing any tone $>25 \mathrm{~dB}$ & $\begin{array}{l}\text { Cumulative noise exposure } \\
\text { (CNE) }\end{array}$ & 6 \\
\hline Burr, 2005 [40] & Denmark & 1237 & $18-59$ & Both & $\begin{array}{l}\text { Never, past, } \\
\text { currently }<15 \mathrm{~g} / \text { day, } \\
\text { currently } \geq 15 \mathrm{~g} / \text { day }\end{array}$ & $\begin{array}{c}\text { Question: 'Do you have reduced } \\
\text { hearing to such an extent that you } \\
\text { feel it is difficult to follow a } \\
\text { conversation between several } \\
\text { people without using a hearing } \\
\text { aid?' }\end{array}$ & $\begin{array}{l}\text { Gender, age and smoking } \\
\text { stratified by occupational noise } \\
\text { exposure }\end{array}$ & 7 \\
\hline \multicolumn{9}{|c|}{ Case-control study } \\
\hline Jiao, 2017 [19] & China & Case 286/control 286 & 40.2 & Both & $\begin{array}{c}\text { Smoker, } \\
\text { Non-smoker }\end{array}$ & $\begin{array}{c}\text { Average hearing threshold } \geq 40 \mathrm{~dB} \\
\text { at } 3,4,6 \mathrm{kHz}\end{array}$ & $\begin{array}{l}\text { Gender, age, job category and } \\
\text { time of exposure to noise }\end{array}$ & 7 \\
\hline Jeffree, 2016 [28] & Malaysia & Case 49/control 98 & 41.3 & Male & $\begin{array}{c}\text { Smoking in } \\
\text { pack-years: } 0,1-10, \\
11-20,>20\end{array}$ & $\begin{array}{c}\text { Average audibility threshold } \geq 25 \\
\mathrm{~dB} \text { at } 0.5,1,2,3 \mathrm{kHz}\end{array}$ & $\begin{array}{l}\text { Daily noise dose, duration of } \\
\text { services, HPD used frequency, } \\
\text { perception about HPD }\end{array}$ & 8 \\
\hline \multicolumn{9}{|c|}{ Cross-sectional study } \\
\hline Wang,2017 [10] & China & 11,196 & 67.1 & Both & $\begin{array}{l}\text { Smoking in } \\
\text { pack-years: } 0,0-25, \\
>25\end{array}$ & $\begin{array}{l}\text { Average audibility threshold } \geq 25 \\
\mathrm{~dB} \text { at } 0.5,1,2,4 \mathrm{kHz} \text { in both ears }\end{array}$ & $\begin{array}{l}\text { Age, sex, race, shift work, } \\
\text { occupational noise exposure, } \\
\text { drinking status, hypertension, } \\
\text { ototoxicity medicine, chronic } \\
\text { diseases (diabetes mellitus, } \\
\text { coronary heart disease, } \\
\text { myocardial infarction and stroke) }\end{array}$ & 10 \\
\hline Sari, 2017 [12] & Indonesia & 122 & $18-40$ & Male & $\begin{array}{c}\text { Smoker, } \\
\text { Non-smoker }\end{array}$ & $\begin{array}{c}\text { Average hearing threshold }>25 \mathrm{~dB} \\
\text { at } 0.5,1,2,4 \mathrm{kHz}\end{array}$ & NA & 6 \\
\hline $\begin{array}{c}\text { Sriopas, } 2017 \\
{[13]}\end{array}$ & Thailand & 180 & $20-50$ & NA & $\begin{array}{c}\text { Pack-years } \\
\text { smoking: }<10, \geq 10\end{array}$ & $\begin{array}{l}\text { Average threshold }>25 \mathrm{~dB} \text { at } 3,4,6, \\
8 \mathrm{kHz}\end{array}$ & $\begin{array}{c}\text { Noise exposure level, } \\
\text { employment duration, age, } \\
\text { factory group, job position, and } \\
\text { education level/noise exposure } \\
\text { level, and education level }\end{array}$ & 8 \\
\hline
\end{tabular}


Table 1. Cont.

\begin{tabular}{|c|c|c|c|c|c|c|c|c|}
\hline $\begin{array}{l}\text { First Author } \\
\text { and Year }\end{array}$ & Country & $n$ & $\begin{array}{l}\text { Mean Age/Age } \\
\text { Range }\end{array}$ & Gender & $\begin{array}{c}\text { Smoking } \\
\text { Information }\end{array}$ & Diagnostic Criteria of NIHL & $\begin{array}{c}\text { Adjusting or Matching } \\
\text { Variables }\end{array}$ & $\begin{array}{c}\text { Quality } \\
\text { Assessment }\end{array}$ \\
\hline \multicolumn{9}{|c|}{ Cross-sectional study } \\
\hline Win, 2015 [29] & Brunei & 543 & 35.6 & Both & $\begin{array}{c}\text { Smoker, } \\
\text { Non-smoker }\end{array}$ & Hearing loss of $>25 \mathrm{~dB}$ at $4 \mathrm{kHz}$ & NA & 7 \\
\hline Sun, 2014 [45] & China & 471 & 39.8 & Male & $\begin{array}{l}\text { Smoker, } \\
\text { Non-smoker }\end{array}$ & $\begin{array}{l}\text { Hearing any tone at } 0.5,1,2 \mathrm{KHz} \\
>25 \mathrm{~dB} \text { or average hearing } \\
\text { threshold } \geq 40 \mathrm{~dB} \text { at } 3,4,6 \mathrm{kHz}\end{array}$ & Age, alcohol & 9 \\
\hline Ferrite, 2013 [31] & Brazil & 364 & 33.9 & Female & $\begin{array}{l}\text { Never smoked, } \\
\text { Past smoker, } \\
\text { Current smoker }\end{array}$ & $\begin{array}{c}\text { Average threshold }>25 \mathrm{~dB} \text { at } 0.5,1 \text {, } \\
2,3,4 \mathrm{kHz} \text { in the worse ear }\end{array}$ & $\begin{array}{l}\text { Age, job type, solvent exposure } \\
\text { and high blood pressure }\end{array}$ & 10 \\
\hline Tao, 2013 [32] & China & 517 & 37.9 & Male & $\begin{array}{c}\text { Smoker, } \\
\text { Non-smoker }\end{array}$ & $\begin{array}{l}\text { Hearing threshold }>40 \mathrm{~dB} \text { at } 4 \mathrm{kHz} \\
\text { in the worse ear }\end{array}$ & Age, CNE & 8 \\
\hline Shen, 2013 [46] & China & 495 & 40.6 & Male & $\begin{array}{c}\text { Smoker, } \\
\text { Non-smoker }\end{array}$ & $\begin{array}{l}\text { Average hearing threshold }>40 \mathrm{~dB} \\
\text { at } 3,4,6 \mathrm{kHz}\end{array}$ & Age, alcohol & 8 \\
\hline Nasir, 2012 [33] & Malaysia & 358 & 31.9 & Both & $\begin{array}{l}\text { Smoker, } \\
\text { Non-smoker }\end{array}$ & $\begin{array}{c}\text { Average hearing threshold } \geq 25 \mathrm{~dB} \\
\text { at } 0.5,1,2,3 \mathrm{kHz}\end{array}$ & $\begin{array}{l}\text { Age, job type, Service duration, } \\
\text { exposure duration, exposure to } \\
\text { explosion, exposure to vibration }\end{array}$ & 9 \\
\hline $\begin{array}{l}\text { Shrestha, } 2011 \\
{[7]}\end{array}$ & Nepal & 110 & 29.8 & Both & $\begin{array}{c}\text { Smoker, } \\
\text { Non-smoker }\end{array}$ & $\begin{array}{l}\text { Average hearing loss }>25 \mathrm{~dB} \text { at } 1,2, \\
3 \mathrm{KHz}\end{array}$ & NA & 6 \\
\hline $\begin{array}{l}\text { Mohammadi, } \\
2010[34]\end{array}$ & Iran & 622 & 42.1 & Male & $\begin{array}{c}\text { Smoker, } \\
\text { Non-smoker; } \\
\text { Smoking in } \\
\text { pack-years: } 0,<20 \text {, } \\
\geq 20\end{array}$ & $\begin{array}{c}\text { Average audibility threshold } \geq 25 \\
\mathrm{~dB} \text { at } 0.5,1,2,3 \mathrm{kHz}\end{array}$ & Age, duration of exposure & 9 \\
\hline $\begin{array}{l}\text { Attarchi, } 2010 \\
{[35]}\end{array}$ & Iran & 478 & 33.5 & Male & $\begin{array}{c}\text { Smoker, } \\
\text { Non-smoker; } \\
\text { Smoking in } \\
\text { pack-years: } 0, \leq 8, \\
>8\end{array}$ & $\begin{array}{c}\text { Hearing threshold differences } \geq 30 \\
\mathrm{~dB} \text { between } 4 \mathrm{KHz} \text { and } 1 \mathrm{KHz} \text { in } \\
\text { both ears }\end{array}$ & Age, duration of exposure & 8 \\
\hline Chang, 2009 [36] & China & 75 & 42.4 & Male & $\begin{array}{c}\text { Smoker, } \\
\text { Non-smoker }\end{array}$ & $\begin{array}{c}\text { Average hearing loss }>25 \mathrm{~dB} \text { at } 0.5, \\
1, \text { and } 2 \mathrm{kHz}\end{array}$ & $\begin{array}{l}\text { Exposure status, age, tea or } \\
\text { coffee, physical activity, BMI }\end{array}$ & 8 \\
\hline $\begin{array}{l}\text { Pouryaghoub, } \\
2007[37]\end{array}$ & Iran & 412 & 42.1 & Male & $\begin{array}{c}\text { Smoking in } \\
\text { pack-years: } 0, \leq 10, \\
>10\end{array}$ & $\begin{array}{l}\text { Hearing threshold }>25 \mathrm{~dB} \text { at } 4 \\
\mathrm{KHz} \text { in the better ear }\end{array}$ & Age, duration of exposure & 8 \\
\hline $\begin{array}{c}\text { Rachiotis, } 2006 \\
{[38]}\end{array}$ & Greece & 145 & 40.3 & Both & $\begin{array}{l}\text { Smoker, } \\
\text { Non-smoker }\end{array}$ & Average threshold $\geq 25 \mathrm{~dB}$ at $4 \mathrm{KHz}$ & $\begin{array}{c}\text { Sex, age, occupational exposure } \\
\text { to waste, duration of } \\
\text { employment }\end{array}$ & 8 \\
\hline $\begin{array}{l}\text { Dement, } 2005 \\
\text { [39] }\end{array}$ & USA & 2469 & 56.6 & Both & $\begin{array}{c}\text { Smoker, } \\
\text { Non-smoker }\end{array}$ & $\begin{array}{l}\text { Index weighted average threshold } \\
>25 \mathrm{~dB} \text { at } 1,2,3 \text {, and } 4 \mathrm{kHz}\end{array}$ & Age, race, and gender & 9 \\
\hline
\end{tabular}


Table 1. Cont

\begin{tabular}{|c|c|c|c|c|c|c|c|c|}
\hline $\begin{array}{l}\text { First Author } \\
\text { and Year }\end{array}$ & Country & $n$ & $\begin{array}{l}\text { Mean Age/Age } \\
\text { Range }\end{array}$ & Gender & $\begin{array}{l}\text { Smoking } \\
\text { Information }\end{array}$ & Diagnostic Criteria of NIHL & $\begin{array}{l}\text { Adjusting or Matching } \\
\text { Variables }\end{array}$ & $\begin{array}{c}\text { Quality } \\
\text { Assessment }\end{array}$ \\
\hline \multicolumn{9}{|c|}{ Cross-sectional study } \\
\hline$\underset{[41]}{\text { Nomura, } 2005}$ & Japan & 163 & $21-66$ & Male & $\begin{array}{l}\text { Never smoked, } \\
\text { Past smoker, } \\
\text { Current smoker }\end{array}$ & Hearing loss $>40 \mathrm{~dB}$ at $4 \mathrm{kHz}$ & NA & 7 \\
\hline $\begin{array}{c}\text { Fortunato, } 2004 \\
\text { [42] }\end{array}$ & Italy & 94 & 43 & Male & $\begin{array}{c}\text { Smokers in } \\
\text { cigarettes/day: } \leq 10, \\
>10\end{array}$ & Hearing any tone $>25 \mathrm{~dB}$ & $\begin{array}{l}\text { PON2 (S/C) and SOD2 IVS3-23 } \\
\text { T/Gmand IVS3-60 T/G } \\
\text { polymorphisms, age }\end{array}$ & 8 \\
\hline $\begin{array}{l}\text { Palmer, } 2004 \\
{[20]}\end{array}$ & Britain & 2232 & $16-64$ & Both & $\begin{array}{l}\text { Never smoked, } \\
\text { Past smoker, } \\
\text { Current smoker }\end{array}$ & $\begin{array}{l}\text { Question: "How well can you hear } \\
\text { a person who is talking to you } \\
\text { when he is sitting on your right } \\
\text { [left] side in a quiet room?". }\end{array}$ & $\begin{array}{l}\text { age, sex, and self report of } \\
\text { frequent }\end{array}$ & 8 \\
\hline $\begin{array}{l}\text { Mizoue, } 2003 \\
{[43]}\end{array}$ & Japan & 1386 & NA & Male & $\begin{array}{l}\text { cigarettes/day: } 0, \\
1-14,15-24, \geq 25\end{array}$ & $\begin{array}{l}\text { Hearing threshold }>25 \mathrm{~dB} \text { at } 1 \mathrm{KHz} \\
\text { and threshold }>40 \mathrm{~dB} \text { at } 4 \mathrm{KHz}\end{array}$ & Age & 8 \\
\hline $\begin{array}{c}\text { Barone, } 1987 \\
{[44]}\end{array}$ & USA & 1210 & 35.4 & Male & $\begin{array}{l}\text { Never smoked, } \\
\text { Past smoker, } \\
\text { Current smoker }\end{array}$ & $\begin{array}{l}\text { Average hearing loss }>25 \mathrm{~dB} \text { at } \\
1,2,3 \mathrm{KHz} \text { with a } 5: 1 \text { weighting of } \\
\text { the better to poorer ear }\end{array}$ & Age, years of present job & 9 \\
\hline
\end{tabular}




\subsection{Association between Current Smokers and Risk of NIHL}

Of the 27 included articles, 29 studies ( 2 articles reported OR separately for different noise exposure history) assessed the association between current smokers and risk of NIHL. Among the 29 studies, 20 reported a positive relationship between current and risk of NIHL, while nine found no association. Figure 2 shows the results of pooled OR by a random effects model. The pooled OR of NIHL for current smokers was 2.05 (95\% CI: 1.71-2.46) with a significant heterogeneity across studies $(Q$ test $\left.P<0.001, I^{2}=87 \%\right)$.

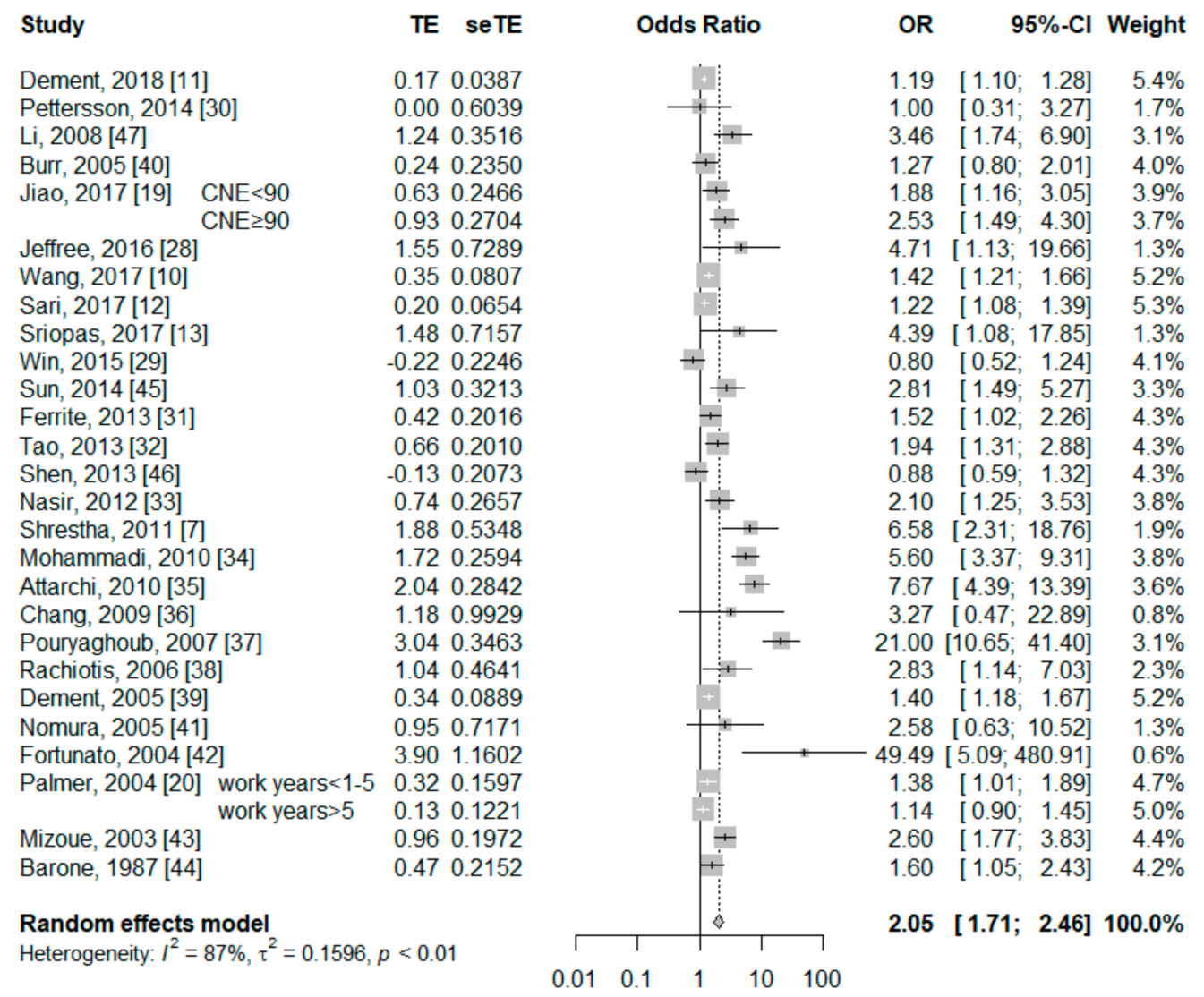

Figure 2. Forest plot for the association between current smokers and NIHL risk.

\subsection{Association between Former Smokers and Risk of NIHL}

Six studies (1 articles reported OR separately for different noise exposure history) provided information on the association between former smokers and risk of NIHL. Supplementary Figure S1 shows the results of pooled OR from a fixed effect model. Of the six included studies, only one showed a positive relationship, while others suggested no statistical significance. The pooled OR of NIHL for former smokers was 1.11 (95\% CI: 1.05-1.18). No heterogeneity was detected ( $Q$ test $P=0.394, I^{2}=4 \%$ ).

\subsection{Subgroup Analyses}

Table 2 shows the results of subgroup analysis for current smokers and NIHL risk. Study design, gender, mean age, race, quality of studies, number of adjusting variables and publication year were conducted in the subgroup analysis. Overall, the results for most subgroups indicate a positive relationship between current smokers and risk of NIHL. According to the study design, the main heterogeneity came from cross-sectional studies ( $Q$ test $P<0.001, I^{2}=89 \%$ ), and for cohort studies and case-control studies, there was no evidence of heterogeneity $\left(Q\right.$ test $P=0.504, I^{2}=0 \%$; $Q$ test $P=0.418$, $I^{2}=0 \%$ ). According to gender, the pooled OR was 3.05 (95\% CI: $\left.1.90-4.89\right)$ for male, 1.50 (95\% CI: 1.28-1.76) for both, and 1.52 (95\% CI: 1.03-2.27) for female. According to race, the pooled OR was 1.88 
(95\% CI: 1.50-2.36) for Mongoloid, 2.41 (95\% CI: 1.70-3.42) for Caucasian, and 1.52 (95\% CI: 1.03-2.27) for others. According to the number of adjusting variables, the pooled OR was 1.58 (95\% CI: 0.86-2.90) for 0, and 2.18 (95\% CI: 1.77-2.69) for $\geq 1$.

Table 2. Results of subgroup analysis between current smokers and NIHL risk.

\begin{tabular}{|c|c|c|c|c|c|}
\hline Subgroup & $\begin{array}{l}\text { Number of } \\
\text { Studies }\end{array}$ & Pooled OR & $95 \% \mathrm{CI}$ & $\begin{array}{c}P \text { Value for } \\
Q \text { Test }\end{array}$ & $I^{2}(\%)$ \\
\hline \multicolumn{6}{|c|}{ Study design } \\
\hline Cohort & 4 & 1.19 & $1.10-1.28$ & 0.504 & 0 \\
\hline Case-control & 3 & 2.25 & $1.59-3.19$ & 0.418 & 0 \\
\hline Cross-sectional & 22 & $\begin{array}{l}2.21 \\
\text { Gender }\end{array}$ & $1.74-2.81$ & $<0.001$ & 89 \\
\hline Both & 13 & 1.50 & $1.28-1.76$ & $<0.001$ & 68 \\
\hline Male & 14 & 3.05 & $1.90-4.89$ & $<0.001$ & 92 \\
\hline \multicolumn{6}{|c|}{ Mean age } \\
\hline$<40$ & 11 & 2.18 & $1.51-3.14$ & $<0.001$ & 86 \\
\hline$\geq 40$ & 16 & $\begin{array}{l}2.03 \\
\text { Race }\end{array}$ & $1.59-2.61$ & $<0.001$ & 89 \\
\hline Mongoloid & 16 & 1.88 & $1.50-2.36$ & $<0.001$ & 76 \\
\hline Caucasian & 12 & 2.41 & $1.70-3.42$ & $<0.001$ & 93 \\
\hline others & 1 & 1.52 & $1.03-2.27$ & - & - \\
\hline \multicolumn{6}{|c|}{ Quality of studies } \\
\hline High quality & 24 & 2.14 & $1.73-2.64$ & $<0.001$ & 88 \\
\hline Moderate quality & 5 & 1.91 & $1.05-3.45$ & $<0.001$ & 82 \\
\hline \multicolumn{6}{|c|}{ Number of adjusting variables } \\
\hline 0 & 4 & 1.58 & $0.86-2.90$ & $<0.001$ & 79 \\
\hline$\geq 1$ & 25 & 2.18 & $1.77-2.69$ & $<0.001$ & 88 \\
\hline \multicolumn{6}{|c|}{ Publication year } \\
\hline$<2010$ & 12 & 2.27 & $1.53-3.34$ & $<0.001$ & 87 \\
\hline$\geq 2010$ & 17 & 1.90 & $1.53-2.36$ & $<0.001$ & 87 \\
\hline
\end{tabular}

\subsection{Dose-Response Analysis}

For the dose-response analysis, a total of 8 studies were included based on our inclusion criteria. The 8 included studies reported data for pack-years of cigarette intake and risk of NIHL. As Figure 3 shows, we observed evidence of non-linear association based on the restricted cubic splines with the random effects model $(P<0.001)$. There was a non-linear increase in risk of NIHL with increasing of pack-years (about or less than 15). Compared with non-smokers, the estimated ORs of NIHL were 2.53 (95\% CI: 1.58-4.05) for five pack-years of cigarette intake, 4.34 (95\% CI: 2.07-9.11) for 10 pack-years, 5.25 (95\% CI: 2.30-11.96) for 15 pack-years, 5.10 (95\% CI: 2.31-11.27) for 20 pack-years, 4.56 (95\%CI: 2.22-9.38) for 25 pack-years, 4.06 (95\% CI: 2.13-7.77) for 30 pack-years, and 3.62 (95\% CI: 2.03-6.46) for 35 pack-years. We found a substantial heterogeneity across studies ( $Q$ test $P<0.001, I^{2}=92.8 \%$ ). 


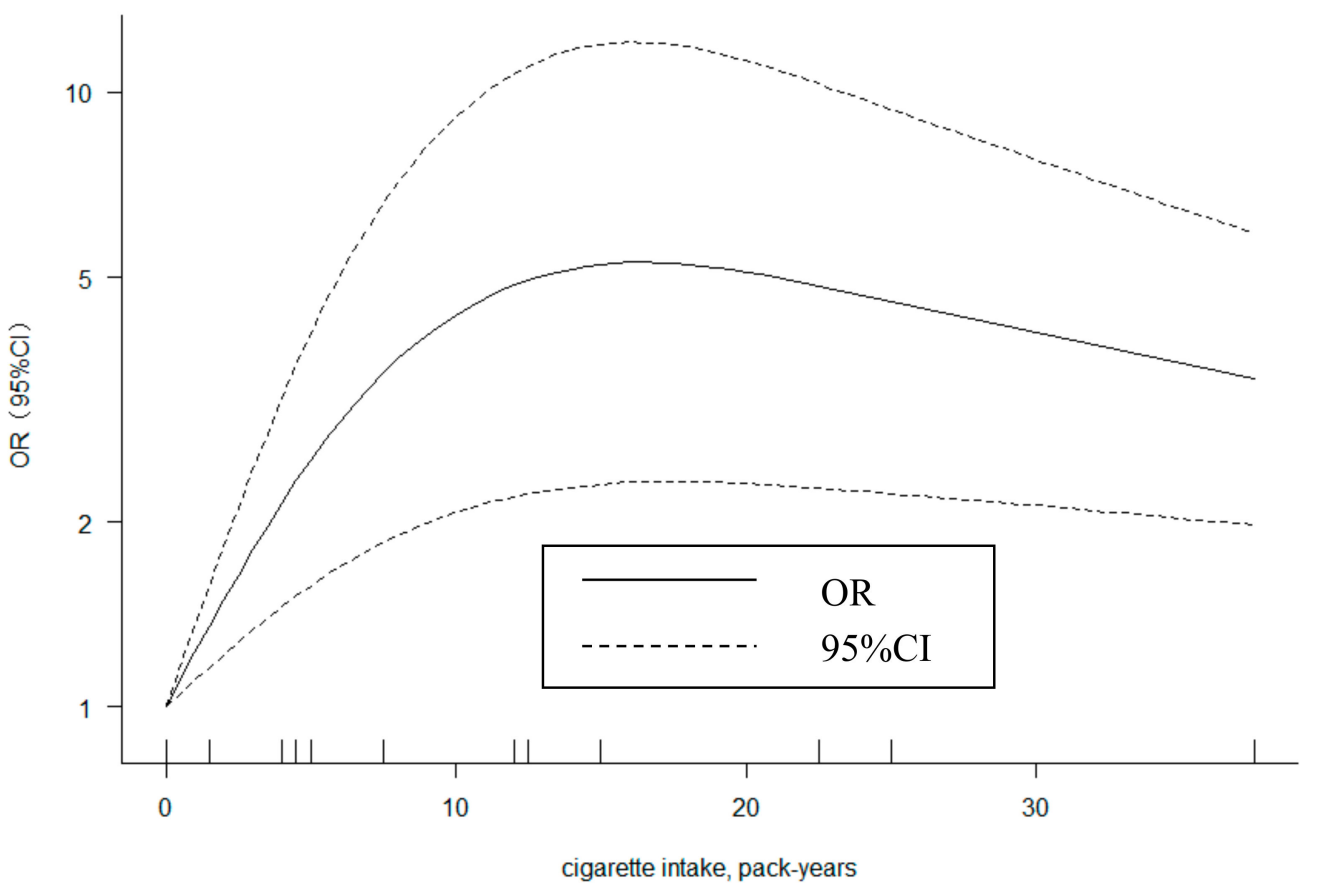

Figure 3. Dose-response relationships for cigarette intake pack-years and NIHL.

\subsection{Sensitivity Analysis and Publication Bias}

The results were not significantly different after omitting two studies $[37,42]$ with extremely high ORs. The sensitivity analysis for current smokers and NIHL risk showed that the result was not significantly affected by removal of any one study. Nevertheless, among studies for former smokers, sensitivity analysis hinted that, omitting the study by Dement [11], the pooled OR would change to 1.18 (95\% CI: 1.00-1.39) (Supplementary Figure S2).

Supplementary Figure S3 shows an asymmetric funnel plot of studies researching the relationship between current smokers and NIHL. It indicated a potential publication bias. In addition, the Begg's rank correlation test and the Egger's linear regression test both confirmed potential publication bias $(P=0.007 ; P<0.001)$. In view of this, we used trim-and-fill method to recalculate the pooled OR. The result was 1.34 (95\% CI: 1.10-1.64), which still indicated the same positive association. Publication bias about former smokers and NIHL was not found by either the Begg's test or the Egger's test $(P=0.091 ; P=0.173)$.

\section{Discussion}

In this meta-analysis, we confirmed the hypothesis that smoking is associated with increased risk of NIHL. Both current smokers and former smokers had a higher risk of NIHL than non-smokers. And we found a dose-response relationship between smoking and NIHL.

However, the specific mechanism of smoking and NIHL is unclear. Nicotine and other substances in tobacco may have ototoxicity, damaging cochlear hair cells by increasing carbon monoxide hemoglobin or reducing the volume of cochlear blood flow [48,49]. In addition, experimental studies have found nicotine-like receptors in hair cell, suggesting that nicotine has a direct ototoxic effect on hair cell function [50]. Smoking may be an independent risk factor for NIHL. Some studies [37] found that the combined effect of smoking and occupational noise was comparable to the sum of the independent effects of each factor. However, other studies [47] indicated that smoking and noise might have a synergistic effect on NIHL.

Our study showed that the pooled OR for current smokers was higher than OR for former smokers, indicating that quitting smoking could reduce the risk of NIHL. It may be associated with the dose-response relationship between smoking and the risk of NIHL risk; former smokers have lower 
exposure to smoke. We performed a dose-response analysis based on eight eligible studies. It showed a non-linear relationship between cigarette intake pack-years and NIHL. The OR and its 95\%CI of each dose are always greater than one. The general trend also showed that the risk of NIHL would increase with the smoking dose increasing. The slow decline in the fitting model may be due to the fact that the dose concentration of the included studies was mainly between 0 and 15 pack-years. In the total of 19 dose points, only three points were larger than 15, which made the latter trend less accurate. In addition, the studies included in the dose-response analysis were mainly cross-sectional studies. There might be a healthy worker effect in the population. Therefore, a smoking cessation program is important for workers in a noise exposure environment.

In the subgroup analysis, we found that heterogeneity mainly came from cross-sectional studies. It is known that the results of cohort and case-control studies are more reliable. But there were no differences in results between the three types of studies. The subgroup analysis by gender showed that the positive association between smoking and NIHL was stronger in male than female. Because the smoking group of women was small, we only included one study focusing on female participants. And in general, men smoke more than women. Further, in the working environment, men generally have a higher noise exposure dose and a longer duration. Some studies suggested that men were more likely to suffer from NIHL as well [51-53]. According to subgroup analysis of race, the OR of current smoking was the highest in the Caucasian population. It may be attributed to genetics, and the previous study indicated that white people were more susceptible to NIHL [54]. Since some cited countries are multi-ethnic, and there are some country-level factors (such as country-specific industry standards for allowable noise levels), the method of simply classifying races based on the country is rough, so the results have some limitations. With regard to number of adjusting variables, group 0 didn't show a positive association. It might attribute to those unadjusted variables (such as age) overwhelming the certain effect of smoking.

Egger's linear regression test and Begg's rank correlation test for the study of current smokers and NIHL were both suggestive of publication bias, which may be related to the inclusion of articles included published in Chinese and English only. In the process of paper screening, four studies published in other languages were eliminated. There was no search for unpublished grey documents. To address the potential of publication bias, we conducted the trim-and-fill method to adjust the influence of publication bias. There was no substantial change, suggesting that the result was not affected by this bias.

Despite previous meta-analysis [15] suggesting that smoking may increase the risk of hearing loss, this study was the first meta-analysis study to explore the relationship between smoking and NIHL. In our study, we focused exclusively on workers with a noise exposure history. Although there was high heterogeneity, subgroup analysis and sensitivity analysis suggested that our results were robust. And a dose-response analysis of pack-years and NIHL was also carried out to assess the dose-response relationship between them.

There are still some limitations in the present study. First, due to the lack of cohort and case-control studies, we added cross-sectional studies. However, cross-sectional studies have a selection bias due to the defects of its design, so that the results are not as reliable as the other two study designs. Secondly, the diagnostic criteria of NIHL were entirely different in each study. Some chose high-frequency $(3 \mathrm{kHz})$ hearing loss as the standard, and some were based on speech frequency $(-2 \mathrm{kHz})$ hearing loss. Moreover, the frequency selections of hearing thresholds were varied as well, which might lead to the heterogeneity. Third, there are also significant differences in the correction of factors that may affect the relationship between smoking and NIHL. The previous studies may not have adjusted all of the confounding factors similarly, such as heredity, with a great effect on NIHL. Fourth, in the dose-response analysis, few of included studies had high dose results, which affected the stability of the rear part of the curve.

According to the shortcomings of our research, we hope to have more long-term follow-up prospective cohort studies to explore the relationship between smoking and NIHL to further confirm 
our conclusions. They also need uniform diagnostic criteria. In addition, the synergistic effect between smoking and noise interests us. We look forward to seeing a subgroup analysis of diverse occupational noise exposure history. Based on the available information, we have reason to believe that smoking is a risk factor for many diseases, and it can affect workers' hearing health. Relevant departments can provide some smoking cessation programs in the occupational noise environment, especially for men. The Government can also reduce tobacco consumption by increasing tobacco taxes.

\section{Conclusions}

In summary, our study indicated that smoking is a risk factor for NIHL. Quitting smoking can reduce the risk of NIHL. There is a non-linear dose-response relationship between the number of smoking pack-years and NIHL. When the dose is less than 15, the risk will add over the increase of pack-years.

Supplementary Materials: The following are available online at http:/www.mdpi.com/1660-4601/17/4/1201/s1, Figure S1: Forest plot for the association between former smokers and NIHL risk, Figure S2: Sensitivity analysis of former smokers and NIHL, Figure S3: Funnel plot of current smokers and NIHL.

Author Contributions: Review conception and design, X.L. and X.R.; Acquisition of data, X.L. and X.R.; Data-interpretation, X.L., X.R., Z.W. and A.L.; Data analysis, X.L.; Drafting of manuscript, X.L.; Critical revision, X.L., X.R., Z.W. and A.L. All authors have read and agreed to the published version of the manuscript.

Funding: This study was funded by the Major Technological Project of Guangzhou Municipal Health and Family Planning Commission, grant 20181A031001.

Conflicts of Interest: The authors declare no conflict of interest.

\section{References}

1. Deafness and Hearing Loss. Available online: https:/www.who.int/en/news-room/fact-sheets/detail/ deafness-and-hearing-loss (accessed on 21 December 2019).

2. Nelson, D.I.; Nelson, R.Y.; Concha-Barrientos, M.; Fingerhut, M. The global burden of occupational noise-induced hearing loss. Am. J. Ind. Med. 2005, 48, 446-458. [CrossRef] [PubMed]

3. Daniel, E. Noise and hearing loss: A review. J. Sch. Health 2007, 77, 225-231. [CrossRef] [PubMed]

4. Hormozi, M.; Ansari-Moghaddam, A.; Mirzaei, R.; Dehghan Haghighi, J.; Eftekharian, F. The risk of hearing loss associated with occupational exposure to organic solvents mixture with and without concurrent noise exposure: A systematic review and meta-analysis. Int. J. Occup. Med. Environ. Health 2017, 30, 521-535. [CrossRef] [PubMed]

5. Yu, S.F.; Chen, G.S.; Jiao, J.; Gu, G.Z.; Zhang, H.L.; Wang, X.M.; Zhou, W.H.; Wu, H.; Li, Y.H.; Zheng, Y.X. A cohort study on occupational noise induced hearing loss in workers at an iron and steel plant. Zhonghua Yu Fang Yi Xue Za Zhi 2017, 51, 13-19. (In Chinese) [CrossRef]

6. Tikka, C.; Verbeek, J.H.; Kateman, E.; Morata, T.C.; Dreschler, W.A.; Ferrite, S. Interventions to prevent occupational noise-induced hearing loss. Cochrane Database Syst. Rev. 2017, 7, CD006396. [CrossRef]

7. Shrestha, I.; Shrestha, B.L.; Pokharel, M.; Amatya, R.C.; Karki, D.R. Prevalence of noise induced hearing loss among traffic police personnel of Kathmandu Metropolitan City. Kathmandu Univ. Med. J. 2011, 9, 274-278. [CrossRef]

8. Sliwinska-Kowalska, M.; Pawelczyk, M. Contribution of genetic factors to noise-induced hearing loss: A human studies review. Mutat. Res. 2013, 752, 61-65. [CrossRef]

9. Torre, P.; Cruickshanks, K.J.; Klein, B.E.K.; Klein, R.; Nondahl, D.M. The association between cardiovascular disease and cochlear function in older adults. J. Speech Lang. Hear. Res. 2005, 48, 473-481. [CrossRef]

10. Wang, D.M.; Wang, Z.C.; Zhou, M.; Li, W.Z.; He, M.A.; Zhang, X.M.; Guo, H.; Yuan, J.; Zhan, Y.; Zhang, K.; et al. The combined effect of cigarette smoking and occupational noise exposure on hearing loss: Evidence from the Dongfeng-Tongji Cohort Study. Sci. Rep. 2017, 7. [CrossRef]

11. Dement, J.; Welch, L.S.; Ringen, K.; Cranford, K.; Quinn, P. Hearing loss among older construction workers: Updated analyses. Am. J. Ind. Med. 2018, 61, 326-335. [CrossRef]

12. Sari, M.A.; Adnan, A.; Munir, D.; Eyanoer, P.C. The correlation of smoking and noise induced hearing loss on workers at a palm oil factory $\mathrm{X}$ in Medan-Indonesia. Bali Med. J. 2017, 6, 637-640. [CrossRef] 
13. Sriopas, A.; Chapman, R.S.; Sutammasa, S.; Siriwong, W. Occupational noise-induced hearing loss in auto part factory workers in welding units in Thailand. J. Occup. Health 2017, 59, 55-62. [CrossRef] [PubMed]

14. Tobacco in China. Available online: https:/www.who.int/china/health-topics/tobacco (accessed on 21 December 2019).

15. Nomura, K.; Nakao, M.; Morimoto, T. Effect of smoking on hearing loss: Quality assessment and meta-analysis. Prev. Med. 2005, 40, 138-144. [CrossRef]

16. Liberati, A.; Altman, D.G.; Tetzlaff, J.; Mulrow, C.; Gotzsche, P.C.; Ioannidis, J.P.A.; Clarke, M.; Devereaux, P.J.; Kleijnen, J.; Moher, D. The PRISMA Statement for Reporting Systematic Reviews and Meta-Analyses of Studies That Evaluate Health Care Interventions: Explanation and Elaboration. Ann. Intern. Med. 2009, 151, W65-W94. [CrossRef]

17. Wells, G.; Shea, B.; O'Connell, D. The Newcastle-Ottawa Scale (NOS) for Assessing the Quality of Nonrandomised Studies in Meta-Analyses; Ottawa Health Research Institute: Ottawa, ON, Canada, 2010.

18. Rostom, A.; Dubé, C.; Cranney, A.; Saloojee, N.; Sy, R.; Garritty, C.; Sampson, M.; Zhang, L.; Yazdi, F.; Mamaladze, V.; et al. Evidence Reports/Technology Assessments; Appendix Quality Assessment; Agency for Healthcare Research and Quality (US): Rockville, MD, USA, 2004.

19. Jiao, J.; Gu, G.Z.; Chen, G.S.; Li, Y.H.; Zhang, H.L.; Yang, Q.Y.; Xu, X.R.; Zhou, W.H.; Wu, H.; He, L.H.; et al. Investigation into the relationship between mitochondrial $12 \mathrm{~S}$ rRNA gene, tRNA gene and cytochrome oxidase II gene variations and the risk of noise-induced hearing loss. Zhonghua Yu Fang Yi Xue Za Zhi 2017, 51, 34-40. (In Chinese) [PubMed]

20. Palmer, K.T.; Griffin, M.J.; Syddall, H.E.; Coggon, D. Cigarette smoking, occupational exposure to noise, and self reported hearing difficulties. Occup. Environ. Med. 2004, 61, 340-344. [CrossRef] [PubMed]

21. Higgins, J.P.T.; Thompson, S.G.; Deeks, J.J.; Altman, D.G. Measuring inconsistency in meta-analyses. Br. Med. J. 2003, 327, 557-560. [CrossRef]

22. Greenland, S.; Longnecker, M.P. Methods for trend estimation from summarized dose-response data, with applications to meta-analysis. Am. J. Epidemiol. 1992, 135, 1301-1309. [CrossRef]

23. Orsini, N.; Li, R.; Wolk, A.; Khudyakov, P.; Spiegelman, D. Meta-analysis for linear and nonlinear dose-response relations: Examples, an evaluation of approximations, and software. Am. J. Epidemiol. 2012, 175, 66-73. [CrossRef]

24. Harrell, F.E., Jr.; Lee, K.L.; Pollock, B.G. Regression models in clinical studies: Determining relationships between predictors and response. J. Natl. Cancer Inst. 1988, 80, 1198-1202. [CrossRef]

25. Egger, M.; Davey Smith, G.; Schneider, M.; Minder, C. Bias in meta-analysis detected by a simple, graphical test. BMJ 1997, 315, 629-634. [CrossRef]

26. Begg, C.B.; Mazumdar, M. Operating characteristics of a rank correlation test for publication bias. Biometrics 1994, 50, 1088-1101. [CrossRef]

27. Duval, S.; Tweedie, R. Trim and fill: A simple funnel-plot-based method of testing and adjusting for publication bias in meta-analysis. Biometrics 2000, 56, 455-463. [CrossRef] [PubMed]

28. Jeffree, M.S.; Ismail, N.; Lukman, K.A. Hearing impairment and contributing factors among fertilizer factory workers. J. Occup. Health 2016, 58, 434-443. [CrossRef] [PubMed]

29. Win, K.N.; Balalla, N.B.P.; Lwin, M.Z.; Lai, A. Noise-Induced Hearing Loss in the Police Force. Saf. Health Work 2015, 6, 134-138. [CrossRef] [PubMed]

30. Pettersson, H.; Burstrom, L.; Hagberg, M.; Lundstrom, R.; Nilsson, T. Risk of Hearing Loss Among Workers with Vibration-Induced White Fingers. Am. J. Ind. Med. 2014, 57, 1311-1318. [CrossRef] [PubMed]

31. Ferrite, S.; Santana, V.S.; Marshall, S.W. Interaction between noise and cigarette smoking for the outcome of hearing loss among women: A population-based study. Am. J. Ind. Med. 2013, 56, 1213-1220. [CrossRef] [PubMed]

32. Tao, L.Y.; Davis, R.; Heyer, N.; Yang, Q.L.; Qiu, W.; Zhu, L.L.; Li, N.; Zhang, H.; Zeng, L.; Zhao, Y.M. Effect of cigarette smoking on noise-induced hearing loss in workers exposed to occupational noise in China. Noise Health 2013, 15, 67-72. [CrossRef] [PubMed]

33. Nasir, H.M.; Rampal, K.G. Hearing loss and contributing factors among airport workers in Malaysia. Med. J. Malays. 2012, 67, 81-86.

34. Mohammadi, S.; Mazhari, M.M.; Mehrparvar, A.H.; Attarchi, M.S. Effect of simultaneous exposure to occupational noise and cigarette smoke on binaural hearing impairment. Noise Health 2010, 12, 187-190. [CrossRef] 
35. Attarchi, M.S.; Labbafinejad, Y.; Mohammadi, S. Contemporary exposure to cigarette smoke and noise of automobile manufacturing company workers. J. Public Health 2009, 18, 245-249. [CrossRef]

36. Chang, S.J.; Chang, C.K. Prevalence and risk factors of noise-induced hearing loss among liquefied petroleum gas (LPG) cylinder infusion workers in Taiwan. Ind. Health 2009, 47, 603-610. [CrossRef] [PubMed]

37. Pouryaghoub, G.; Mehrdad, R.; Mohammadi, S. Interaction of smoking and occupational noise exposure on hearing loss: A cross-sectional study. BMC Public Health 2007, 7, 137. [CrossRef] [PubMed]

38. Rachiotis, G.; Alexopoulos, C.; Drivas, S. Occupational exposure to noise, and hearing function among electro production workers. Auris Nasus Larynx 2006, 33, 381-385. [CrossRef] [PubMed]

39. Dement, J.; Ringen, K.; Welch, L.; Bingham, E.; Quinn, P. Surveillance of hearing loss among older construction and trade workers at Department of Energy nuclear sites. Am. J. Ind. Med. 2005, 48, 348-358. [CrossRef]

40. Burr, H.; Lund, S.P.; Sperling, B.B.; Kristensen, T.S.; Poulsen, O.M. Smoking and height as risk factors for prevalence and 5-year incidence of hearing loss. A questionnaire-based follow-up study of employees in Denmark aged 18-59 years exposed and unexposed to noise. Int. J. Audiol. 2005, 44, 531-539. [CrossRef]

41. Nomura, K.; Nakao, M.; Yano, E. Hearing loss associated with smoking and occupational noise exposure in a Japanese metal working company. Int. Arch. Occup. Environ. Health 2005, 78, 178-184. [CrossRef]

42. Fortunato, G.; Marciano, E.; Zarrilli, F.; Mazzaccara, C.; Intrieri, M.; Calcagno, G.; Vitale, D.F.; La Manna, P.; Saulino, C.; Marcelli, V.; et al. Paraoxonase and superoxide dismutase gene polymorphisms and noise-induced hearing loss. Clin. Chem. 2004, 50, 2012-2018. [CrossRef]

43. Mizoue, T.; Miyamoto, T.; Shimizu, T. Combined effect of smoking and occupational exposure to noise on hearing loss in steel factory workers. Occup. Environ. Med. 2003, 60, 56-59. [CrossRef]

44. Barone, J.A.; Peters, J.M.; Garabrant, D.H.; Bernstein, L.; Krebsbach, R. Smoking as a risk factor in noise-induced hearing loss. J. Occup. Med. 1987, 29, 741-745.

45. Sun, H.; Zhang, X. Influence of Smoking and Alcohol Drinking on Hearing Loss Among Workers Exposed to Industrial Noise. J. Prev. Med. Inf. 2014, 30, 391-394. (In Chinese) [CrossRef]

46. Shen, H.; Shi, J. Influence of smoking and drinking on noise-induced hearing loss. Chin. J. Ind. Med. 2013, 26, 741-745. (In Chinese)

47. Li, X.; Li, Y. Study of Interaction between Smoking and Occupational Noise Exposure on Hearing Loss. J. Trop. Med. 2008, 8, 441-444. (In Chinese)

48. Browning, G.G.; Gatehouse, S.; Lowe, G.D. Blood viscosity as a factor in sensorineural hearing impairment. Lancet 1986, 1, 121-123. [CrossRef]

49. Fechter, L.D.; Thorne, P.R.; Nuttall, A.L. Effects of carbon monoxide on cochlear electrophysiology and blood flow. Hear. Res. 1987, 27, 37-45. [CrossRef]

50. Blanchet, C.; Erostegui, C.; Sugasawa, M.; Dulon, D. Acetylcholine-induced potassium current of guinea pig outer hair cells: Its dependence on a calcium influx through nicotinic-like receptors. J. Neurosci. 1996, 16, 2574-2584. [CrossRef]

51. Attias, J.; Sapir, S.; Bresloff, I.; Reshef-Haran, I.; Ising, H. Reduction in noise-induced temporary threshold shift in humans following oral magnesium intake. Clin. Otolaryngol. Allied Sci. 2004, 29, 635-641. [CrossRef]

52. Niskar, A.S.; Kieszak, S.M.; Holmes, A.E.; Esteban, E.; Rubin, C.; Brody, D.J. Estimated prevalence of noise-induced hearing threshold shifts among children 6 to 19 years of age: The Third National Health and Nutrition Examination Survey, 1988-1994, United States. Pediatrics 2001, 108, 40-43. [CrossRef]

53. Cruickshanks, K.J.; Nondahl, D.M.; Tweed, T.S.; Wiley, T.L.; Klein, B.E.; Klein, R.; Chappell, R.; Dalton, D.S.; Nash, S.D. Education, occupation, noise exposure history and the 10-yr cumulative incidence of hearing impairment in older adults. Hear. Res. 2010, 264, 3-9. [CrossRef]

54. Ishii, E.K.; Talbott, E.O. Race/ethnicity differences in the prevalence of noise-induced hearing loss in a group of metal fabricating workers. J. Occup. Environ. Med. 1998, 40, 661-666. [CrossRef]

(C) 2020 by the authors. Licensee MDPI, Basel, Switzerland. This article is an open access article distributed under the terms and conditions of the Creative Commons Attribution (CC BY) license (http://creativecommons.org/licenses/by/4.0/). 